\title{
Penerapan Model Team Quiz Dengan Media Gambar dalam Peningkatan Keterampilan Berbicara pada Siswa Kelas V SDN 2 Krakal Tahun Ajaran 2017/2018.
}

\section{Devi Novitasari ${ }^{1}$, Imam Suyanto², Suhartono ${ }^{3}$}

1,2,3 Universitas Sebelas Maret

devinovitasari@gmail.com

\section{Article History \\ accepted 01/02/2019}

approved 01/03/2019 published 01/04/2019

\begin{abstract}
The purposes of this research were (1) to find out whether the applycations of team quiz models with picture card media can improve the ability of Indonesian speaking skill to V graders of SDN 2 Krakal in the academic year 2017/2018, (2) to describe how the use of team quiz models with pictures card media which can enhance the ability of Indonesian speaking skill to $V$ graders of Prmary school. This's Class Action Reseach (CAR)on two cycle whith two action each cycle. In the pre-action mastery percentage reached $4,54 \%$ of new students, having performed the action in the first cycle of students completeness percentage increased to $72,72 \%$, in the second cycle increased to $86,35 \%$. It's was using the steps as following : a) showing the picture(b) selection of topics, (c) group sharing, (d) delivery of lesson formats, (e) delivery of material with images, (f) intergroup quizzes, $(g)$ collective inference. Model Team Quiz with image media can improve students' speaking skills proven on pre-action percentage mastery of new students reached $4.54 \%$, after the action done in cycle I the percentage of students mastery increased to $72.72 \%$, in cycle II increased to $86.36 \%$.
\end{abstract}

Keywords: team quiz model, picture media, speaking ability, Indonesian anguages.

\section{Abstrak}

Tujuan penelitian ini adalah (1) untuk mendeskripsikan bagaimana penerapan pembelajaran model Team Quiz yang dapat meningkatkan keterampilan berbicara siswa kelas $\mathrm{V}$ sekolah dasar. (2) Untuk meningkatkan pembelajaran Bahasa Indonesia tentang peningkatan keterampilan berbicara siswa kelas V SDN 2 Krakal Tahun Ajaran 2017/2018 melalui penerapan pembelajaran model Team Quiz; Penelitian ini merupakan Penelitian Tindakan Kelas (PTK) dilaksanakan dalam 2 siklus dengan dua kali pertemuan tiap siklusnya dengan jumlah siswa sebanyak 22 siswa. Hasil penelitian ini menunjukkan. Langkah-langkah Penerapan model Team Quiz dengan media gambar menggunakan langkah-langkah sebagai berikut: a) pengenalan media gambar, (b) pemilihan topik, (c) pembagian kelompok, (d) penyampaian format pelajaran, (e) penyampaian materi dengan gambar, (f) kuis antar kelompok, (g) penyimpulan bersama. Model Team Quiz dengan media gambar dapat meningkatkan keterampilan berbicara siswa terbukti pada pra tindakan persentase ketuntasan siswa baru mencapai $4,54 \%$, setelah dilaksanakan tindakan pada siklus I persentase ketuntasan siswa meningkat menjadi $72,72 \%$, pada siklus II meningkat menjadi $86,36 \%$

Kata kunci: team quiz, keterampilan berbicara, bahasa Indonesia 


\section{PENDAHULUAN}

Pendidikan dasar memiliki tujuan meletakan dasar, kecerdasan, pengetahuan, kepribadian, akhlak mulia, serta keterampilan untuk hidup mandiri dan mengikuti pendidikan lebih lanjut. Untuk mencapai tujuan pendidikan nasional, salah satu upaya yang dilakukan secara menyeluruh meliputi aspek pengetahuan, keterampilan, sikap dan nilai nilai. Dalam mencapai tujuan yang diharapkan, ada beberapa fakor yang mempengaruhi pencapaian tujuan tersebut. Faktor-faktor tersebut berupa sarana dan prasarana pendidikan, sarana pendidikan berupa peralatan dan perlengkapan yang secara langsung digunakan untuk menunjang pendidikan, seperti gedung ruang kelas, meja, kursi, alat dan media pembelajaran. Adapun Standar Kompetensi Lulusan Satuan Pendidikan (SKL-SP) antara lain adalah berkomunikasi secara jelas dan santun, bekerja sama dalam kelompok, tolong-menolong, dan menjaga diri sendiri dalam lingkungan keluarga dan teman sebaya, menunjukan kegemaran membaca dan menulis, menunjukkan keterampilan menyimak, berbicara, membaca, menulis, dan berhitung (Permendiknas no.23 tahun 2006).

Sesuai dengan Kurikulum Tingkat Satuan Pendidikan atau KTSP (2007:73) di Sekolah Dasar, pembelajaran bahasa Indonesia diarahkan untuk meningkatkan kemampuan siswa dalam berkomunikasi dengan bahasa Indonesia yang baik dan benar, baik secara lisan maupun tulisan, serta menumbuhkan apresiasi terhadap hasil karya kesastraan Bangsa Indonesia. Ruang lingkup mata pelajaran bahasa Indonesia di Sekolah Dasar (SD) mencakup komponen kemampuan berbahasa dan kemampuan bersastra yang meliputi aspek - aspek: mendengarkan, berbicara, membaca, dan menulis. Kemampuan atau keterampilan berbicara merupakan bagian dari pengajaran bahasa Indonesia Dalam Kurikulum Tingkat Satuan Pendidikan Sekolah Dasar (2007: 74) dijelaskan bahwa tujuan mata pelajaran bahasa Indonesia adalah agar siswa memiliki kemampuan berkomunikasi secara efektif dan efisien dengan etika yang berlaku baik secara lisan maupun tulis, menggunakan bahasa Indonesia untuk meningkatkan kemampuan intelektual, serta kematangan emosional dan sosial. Oleh sebab itu, sangat dibutuhkan ketrampilan dari salah satu aspek seperti berbicara, keterampilan berbicara merupakan keterampilan yang penting dalam kehidupan sehari-hari sebagai media komunikasi lisan yang efektif.

Berdasarkan pengamatan yang dilakukan oleh peneliti pada, pembelajaran Bahasa Indonesia tentang keterampilan bebicara di SDN 2 Krakal khususnya kelas $\mathrm{V}$ masih belum optimal. Hal ini ditunjukkan dari keseluruhan peserta didik yang terdiri dari 22 siswa (10 perempuan dan 12 laki-laki), baru 4,5\% siswa (1 siswa) yang memperoleh nilai di atas Kriteria Ketuntasan Maksimal (KKM). Sedangkan 95,5\% (21 siswa) siswa masih belum mencapai KKM yang telah ditetapkan yaitu 75 . Berdasarkan hasil observasi terhadap siswa kelas V SD Negeri 2 Krakal dalam pembelajaran Bahasa Indonesia khususnya berbicara, dapat diketahui bahwa keaktifan belajar siswa dalam berbicara masih rendah.

Sebagian besar para siswa tergolong pasif dan mereka cenderung tidak berani untuk bertanya kepada guru apabila ada hal yang belum dimengerti. Keberanian siswa kelas $\mathrm{V}$ dalam pembelajaran Bahasa Indonesia untuk menyampaikan pendapat baik itu, bertanya, menjawab pertanyaan dari guru maupun menyampaikan pendapat masih belum tampak, karena guru tidak membiasakan siswa untuk berbicara. Guru di kelas masih berperan sebagai pusat pembelajar dan siswa hanya dibiarkan duduk, dengar, catat dan hafal dan tidak dibiasakan untuk belajar secara aktif. Guru belum menggunakan metode yang tepat untuk melibatkan siswa secara langsung, sehingga anak terbiasa untuk diam, takut berpendapat, dan tidak berani bertanya. Keaktifan belajar siswa yang rendah tersebut berpengaruh terhadap hasil belajarnya yang cenderung rendah juga. Selain itu penggunaan model dan metode dalam pembelajaran yang belum bervariasi, yaitu model yang digunakan masih konvensional serta metode yang diterapkan didominasi oleh ceramah. Penggunaan metode ceramah 
yang terlalu banyak membuat siswa bosan, jenuh, dan pembelajaran lebih didominasi oleh guru sehingga siswa kurang aktif. Salah satu alternatif agar pembelajaran tidak berpusat pada guru adalah penggunaan model pembelajaran kooperatif teknik Team Quiz. Menurut Suprijono (2014 : 114) Metode ini mampu meningkatkan kemampuan siswa bertanggung jawab terhadap apa yang mereka pelajari melalui cara yang menyenangkan dan tidak menakutkan.

Metode pembelajaran Team Quiz merupakan model pembelajaran aktif siswa dibagi kedalam tiga kelompok besar, masing-masing anggota kelompok mempunyai tanggung jawab yang sama atas keberhasilan kelompoknya dalam memahami materi dan menjawab soal. Tipe Team Quiz ini diawali dengan menerangkan materi pelajaran secara klasikal, lalu siswa dibagi kedalam kelompok besar. Semua anggota kelompok bersama-sama mempelajari materi tersebut melalui lembaran kerja. Mereka mendiskusikan materi tersebut, saling memberi arahan, saling memberikan pertanyaan dan jawaban untuk memahami materi tersebut. Setelah selesai materi maka diadakan suatu pertandingan akademis. Dengan adanya pertandingan akademis ini maka terciptalah kompetisi antar kelompok, para siswa akan senantiasa berusaha belajar dengan motivasi yang tinggi agar dapat memperoleh nilai yang tinggi dalam pertandingan.

Agar pembelajaran lebih menarik dan menjadikan siswa mudah dalam menerima informasi dari guru, maka perlu adanya suatu media. Arsyad (2011: 3) berpendapat "Media dalam proses belajar menagajar cenderung diartikan sebagai alatalat grafis, fotografis, atau elektonis untuk menangkap, memproses dan menyusun kembali informasi visual atau verbal". Media atau alat peraga akan memudahkan guru dalam menyampaikan suatu materi pembelajaran. Selain itu, media juga dapat memberikan daya tarik terhadap siswa untuk memperhatikan dan memahami materi, sehingga siswa akan lebih mudah menerima dan memahami materi yang disampaikan guru. Dalam pemilihan media juga tidak sembarangan, apabila media yang digunakan tidak sesuai dengan materi yang sedang diajarkan, maka akan menimbulkan ketidak efektifan media tersebut, bukannya membantu dalam pelaksanaannya tapi justru akan membingungkan siswa. Melatih siswa untuk meningkatkan keterampilan berbicara dapat menggunakan media gambar dengan tema yang bervariasi, sehingga siswa lebih mudah untuk menuangkan gagasan berdasarkan gambar yang digunakan oleh guru dalam pembelajaran.

Penerapan model Team Quiz dengan media gambar dalam pengajaran keterampilan berbicara akan saling membantu dalam mengembangkan keterampilan berbicara dan semangat siswa dalam mengikuti pembelajaran. Model Team Quiz ini mudah diterapkan pada siswa kelas $\mathrm{V}$ karena model pembelajaran ini cukup sederhana dan menyenangkan serta dapat menumbuhkan semangat dan motivasi siswa selama pembelajaran.

Berdasarkan uraian latar belakang maka rumusan masalah dalam penelitian ini adalah sebagai berikut: Bagaimana langkah-langkah penerapan model Team Quiz dengan media gambar tersebut dalam meningkatkan keterampilan berbicara pada siswa kelas V SD dan apakah penerapan model Team Quiz dengan media gambar dapat meningkatkan keterampilan berbicara pada siswa kelas V SD.

Berdasarkan rumusan masalah yang ditetapkan, maka tujuan penelitian tundakan kelas ini adalah sebagai berikut: (1) Untuk mendeskripsikan bagaimana penerapan pembelajaran model Team Quiz yang dapat meningkatkan keterampilan berbicara siswa kelas V SD Negeri 2 Krakal Kecamatan Alian, Kabupaten Kebumen Tahun Ajaran 2017/2018. (2) Untuk meningkatkan pembelajaran Bahasa Indonesia tentang peningkatan keterampilan berbicara siswa kelas V SDN 2 Krakal Tahun Ajaran 2017/2018 melalui penerapan pembelajaran model Team Quiz. 


\section{METODE}

Penelitian dilaksanaka di kelas V SDN 2 Krakal Kecamatan Alian Kabupaten Kebumen. Jumlah subjek penelitian 22 siswa yang terdiri atas 10 siswa laki-laki dan 12 siswa perempuan. Waktu penelitian dilaksanakan mulai bulan Oktober 2017 sampai dengan bulan November 2017 pada semester satu tahun ajaran 2017/2018.

Adapun alat pengumpulan data dalam penelitian ini dibagi menjadi dua, yaitu instrumen tes dan non tes. Instrumen tes berupa lembar soal evaluasi hasil belajar siswa, sedangkan instrumen non tes terdiri dari lembar observasi yang digunakan sebagai alat pengumpul data terhadap jalannya pelaksana- an kegiatan pembelajaran bahasa Indonesia kelas $\mathrm{V}$ dengan menerapkan model Team Quiz dengan media gambar yang sesuai dengan RPP dan skenario pembelajaran yang telah disusun. Peneliti berkolaborasi dengan guru kelas dalam menentukan tindakan sesuai dengan kondisi siswa kelas $\mathrm{V}$, kemudian pelaksana tindakan dalam penelitian ini adalah guru kelas. Observer dalam penelitian ini terdiri dari 2 guru kelas (kelas 1, dan 4). Data yang diperoleh dalam penelitian ini dibagi menjadi dua yaitu data yang bersumber dari hasil UTS dan data tindakan yang berupa hasil penelitian.

Analisis data dilakukan melalui analisis deskriptif komparatif untuk membandingkan data kuantitatif berupa data nilai hasil belajar siswa tiap siklus dan analisis kualitatif yang mengacu pada pendapat Miles dan Hiberman (1984), meliputi tiga alur kegiatan yaitu reduksi data, penyajian data, dan penarikan kesimpulan, yang dilakukan selama dan setelah pengumpulan data selesai (Sugiyono, 2008: 246-253). Untuk menguji dan menjaga keabsahan data, digunakan teknik triangulasi berupa triangulasi sumber dan triangulasi teknik. Triangulasi sumber dilakukan dengan mempertimbangkan data yang bersumber dari siswa, observer dan peneliti. Sedangkan dengan triangulasi teknik peneliti mem- pertimbangkan teknik observasi dan dokumen. Prosedur penelitian ini menggunakan metode penelitian tindakan kelas (class action research). Langkah atau prosedur penelitian tindakan kelas tersebut yaitu perencanaan tindakan, pelaksanaan tindakan, pengamatan, dan refleksi. Pada tahap perencanaan, peneliti melakukan koordinasi dengan guru kelas untuk menentukan tindakan yang akan diambil sesuai kondisi siswa kelas V, menyusun RPP dan skenario pembelajaran, mempersiapkan sarana pembelajaran dan mempersiapkan instrumen penelitian. Dalam penelitian tindakan kelas ini menggunakan model penelitian yang dikembangkan oleh Kasbolah (2001) dengan langkah atau alur penelitian dimulai dari perencanaan, pelaksanaan, observasi, dan refleksi tindakan yang dapat dijadikan rencana tindakan berikutnya.

Pada pelaksanaannya, tahapan ini selalu ber-hubungan dan berkelanjutan dalam prosesnya, serta mengalami perbaikan-perbaikan sesuai dengan hasil observasi dan refleksi hingga memenuhi hasil atau tujuan yang diharapkan.

\section{HASIL DAN PEMBAHASAN}

Usaha untuk meningkatkan keterampilan berbicara siswa kelas V SDN 2 Krakal dengan menerapankan pembelajaran model Team Quiz dengan media gambar dilaksanakan dengan dua siklus. Setiap siklusnya terdiri dari dua pertemuan, dengan alokasi waktu 3x35 menit setiap pertemuan. . Langkah-langkah penerapan model Team Quiz pada penelitian ini adalah sebagai berikut: : a) pengenalan media gambar, (b) pemilihan topik, (c) pembagian kelompok, (d) penyampaian format pelajaran, (e) penyampaian materi dengan gambar, (f) kuis antar kelompok, (g) penyimpulan bersama. Data rata-rata hasil observasi yang diperoleh dari dua orang observer terkait penerapan pembelajaran model Team Quiz dengan media gambar pada pembelajaran Bahasa Indonesia oleh guru pada siklus I sampai siklus II adalah sebagai berikut: 
Tabel 1. Hasil Observasi Guru dalam Mengajar Pada Siklus I dan II

\begin{tabular}{|c|c|c|c|}
\hline \multicolumn{2}{|c|}{ Langkah Pemb. } & \multirow[t]{2}{*}{ Rata-rata } & \multirow[b]{2}{*}{ Kategori } \\
\hline Si. I & Si. II & & \\
\hline 73,80 & 85,18 & 79,49 & Baik \\
\hline
\end{tabular}

Berdasarkan tabel 1 dapat disimpulkan bahwa persentase rata-rata guru dalam mengajar dengan menerapkan langkah-langkah Penerapan pembelajaran model Team Quiz dengan media gambar pada siklus I mencapai $73,80 \%$, sedangkan pada siklus II mencapai $85,18 \%$. Persentase rata-rata guru dalam mengajar dengan langkah Penerapan pembelajaran model Team Quiz dengan media gambar adalah $79,49 \%$ dengan kategori baik. Adapun hasil observasi penerapan pembelajaran model Team Quiz dengan media gambar terhadap siswa pada siklus I sampai siklus II dapat dilihat pada tabel berikut:

Tabel 2. Hasil Observasi Siswa pada Siklus I dan II

\begin{tabular}{|c|c|c|c|}
\hline Langk & Pemb & Rata-rata & Kategor \\
\hline Si. I & Si. II & & \\
\hline 74,91 & 85,71 & 80,31 & Baik \\
\hline
\end{tabular}

Dari tabel 2 dapat disimpulkan bahwa skor rata-rata Penerapan pembelajaran model Team Quiz dengan media gambar terhadap siswa pada siklus I mencapai 74,91 sedangkan pada siklus II mencapai 85,71. Persentase rata-rata Penerapan pembelajaran model Team Quiz dengan media gambar pada siswa mencapai 80,31 dengan kategori baik. Sedangkan perolehan rata-rata nilai hasil belajar siswa pada hasil uts, siklus I, siklus II adalah sebagai beikut:

Tabel 3. Perolehan Hasil Keterampilan Berbicara

\begin{tabular}{lcccc}
\hline \multirow{2}{*}{ Tindakan } & \multicolumn{3}{c}{ Hasil Belajar BI } \\
\cline { 2 - 5 } & \multicolumn{2}{c}{ Tuntas } & \multicolumn{3}{c}{ Belum Tuntas } \\
\cline { 2 - 5 } & Frek. & $\%$ & Frek. & $\%$ \\
\hline Pra siklus & 1 & 4,54 & 21 & 95,45 \\
Sik. I & 16 & 72,72 & 6 & 27,27 \\
Sik. II & 19 & 86,35 & 3 & 13,65
\end{tabular}

Berdasarkan tabel 3 menunjukkan bahwa hasil belajar Bahasa Indonesia siswa kelas $\mathrm{V}$ semakin meningkat. Hal tersebut ditunjukkan pada hasil uts, siswa yang mencapai nilai hasil belajar $\geq$ KKM baru mencapai 4,54\% atau sebanyak 1 siswa. Pada siklus I kektuntasan hasil belajar siswa meningkat menjadi $72,72 \%$ atau sebanyak 16 siswa. Selanjutnya, pada siklus II ketuntasan siswa meningkat menjadi $86,35 \%$ atau sebanyak 19 siswa.

Penerapan pembelajaran model Team Quiz dengan media gambar dalam pembelajaran yang dilakukan sesuai dengan langkah-langkah yang ada pada landasan teori dan selalu diperbaharui sesuai karakter siswa. Penelitian yang telah dilakukan telah menemukan langkah-langkah yang tepat dalam peningkatan hasil belajar bahasa Indonesia siswa kelas V SD Negeri 2 Krakal dengan menemui beberapa kendala. Berikut adalah langkah-langkah yang diterapkan untuk meningkatkan keterampilan berbicara Bahasa Indonesia sebagai berikut: : a) pengenalan media gambar, (b) pemilihan topik, (c) pembagian kelompok, (d) penyampaian format pelajaran, (e) penyampaian materi dengan gambar, (f) kuis antar kelompok, (g) penyimpulan bersama. Aktivitas proses belajar yang tepat sesuai langkah-langkah dan karakterisitk siswa dapat mempengaruhi hasil belajar. 
Tindakan siklus pertama guru masih belum beradaptasi dengan pembelajaran model Team Quiz dengan media gambar, hal ini didasarkan dari hasil pengamatan dan wawancara yang dilakukan. Pertemuan kedua guru masih menjajagi karakteristik siswa yang tepat dengan penerapan pembelajaran model Team Quiz dengan media gambar. Secara garis besar pada tindakan siklus pertama guru masih mendominasi dalam penerapan pembelajaran model Team Quiz dengan media gambar sedangkan siswa hanya mengikuti arahan dari guru saja. Depdiknas (2003) menyatakan belajar sebagai proses interaksi peserta didik dengan pendidik dan sumber belajar pada suatu lingkungan belajar dalam hal ini lingkungan yang ditekankan ialah lingkungan belajar kelas, interaksi antara peserta didik dan pendidik yang dapat memaksimalkan proses belajar dan akan tampak pada evaluasi. Hal ini mendapat catatan oleh observer kepada guru kelas selanjutnya untuk di diskusikan dengan peneliti, observer juga menyadari akan hal tersebut karena penelitian baru berjalan beberapa pertemuan dan membutuhkan adaptasi terhadap siswa dan pembelajaran. Secara keseluruhan tes hasil belajar dan indikator pencapaian proses belajar belum tercapai, sehingga peneliti melanjutkan pada siklus selanjutnya.

Tindakan siklus dua, guru melaksanakan pembelajaran sesuai skenario dan langkah penerapan pembelajaran model Team Quiz dengan media gambar pada pertemuan sebelumnya. Ketika otak sudah dapat bersinergis dalam bekerja, dan melakukan pengulangan dalam setiap mendapatkan informasi maka seketika itu akan menghasilkan daya ingat yang luar biasa, itulah alasan yang diharapkan dari penerapan pembelajaran model Team Quiz dengan media gambar. Secara keseluruhan penerapan pembelajaran model Team Quiz dengan media gambar sudah sesuai indikator pencapaian dan pembelajaran juga sudah sesuai dengan indikator. $\mathrm{Hal}$ tersebut dianalisis dari pengamatan yang dilakukan oleh observer. Pencapaian tersebut semata-mata bukan hal tidak mustahil untuk dapat dimaksimalkan, karena masih ditemui kendala yang dapat diminimalisir agar tujuan yang ingin dicapai dapat lebih dimaksimalkan.

Berdasarkan pencapaian indikator-indikator penelitian antar siklus dapat dinyatakan bahwa penerapan pembelajaran model Team Quiz dengan media gambar dapat meningkatkan kemampuan Berbicara siswa kelas V SD Negeri 2 Krakal. Aktivitas penerapan pembeljaran model Team Quiz dengan media gambar dilakukan melalui tahapan yang benar dan terus diperbaharui sesuai karakteristik siswa. Dinyatakan oleh Piaget tentang karakteristik anak sesuai perkembangannya dibedakan menjadi 4 tahap, yaitu sensorimotor, prooperasional, operasional konkrit, dan operasi formal. Berdasarkan hal tersebut anak kelas 5 sudah dapat berfikir konkrit, sudah dapat berfikir logis (Sumantri dan Syaodih, 2009

Menurut Buzan penggunaan warna, garis lengkung, simbol, kata, dan gambar yang sesuai dengan satu rangkaian aturan yang sederhana, mendasar, alami, akan sesuai dengan kerja otak kanan dan kiri akan menciptakan proses belajar yang berkesan pada siswa. Pembelajaran akan lebih hidup dan bermakna, siswa akan menjadi lebih bersemangat dalam kegiatan belajar mengajar (2010). Winataputra, dkk (2008) berpendapat bahwa tujuan pembelajaran mengacu pada kemampuan atau kompetensi yang diharapkan dimiliki siswa setelah mengikuti suatu pembelajaran tertentu. Kemampuan tersebut bisa dilihat dari proses yang ada dan tertuang dalam evaluasi yang dilakukan. Hal tersebut membuktikan bahwa begitu pentingnya proses belajar dalam pembelajaran yang dapat mempengaruhi tes hasil belajar. Berdasarkan hal tersebut dan tercermin dalam penelitian yang menunjukan bahwa penerapan pembelajaran model Team Quiz dengan media gambar pada suiswa kelas V SD dapat meningkatkan keterampilan berbicara siwa kelas V SD Negeri 2 Krakal tahun Ajaran 2017/2018. 


\section{SIMPULAN}

Berdasarkan hasil penelitian dan pembahasan yang telah dijelaskan diatas. Maka dapat disimpulkan bahwa: Penerapan Model Team Quiz dengan Media Gambar Dalam Peningkatan Keterampilan Berbicara pada Siswa Kelas V SD N 2 Krakal, Kecamatan Alian, Kabupaten Kebumen Tahun Ajaran 2017/2018 dengan menggunakan langkah-langkah: a) pengenalan media gambar, (b) pemilihan topik, (c) pembagian kelompok, (d) penyampaian format pelajaran, (e) penyampaian materi dengan gambar, (f) kuis antar kelompok, (g) penyimpulan bersama.

Penerapan Model Team Quiz dengan Media Gambar terbukti dapat meningkatkan keterampilan berbicara siswa itu terbukti dengan meningkatnya hasil kemampuan berbicara siswa setelah penelitian ini dilaksanakan. Sebelum penelitian ini dilaksanakan, keterampilan berbicara siswa tergolong rendah, dengan rincian siswa dengan keterampilan berbicara $\geq 75$ hanya sebanyak $4,54 \%$ dari jumlah keseluruhan siswa kelas V. Setelah penelitian ini dilaksanakan, terjadi peningkatan keterampilan berbicara siswa yang ditunjukkan oleh meningkatnya rata-rata keretampilan berbicara siswa kelas $\mathrm{V}$ hingga mencapai 86,35dari jumlah keseluruhan siswa kelas V.

Selanjutnya, dari hasil penelitian di-atas, peneliti memberikan saran Sekolah hendaknya mengupayakan ketersediaan alat peraga atau media pembelajaran khususnya media pembelajaran yang berhubungan dengan mata pelajaran Bahasa Indonesia dan alat peraga pada umumnya. Upaya tersebut diharapkan dapat lebih menunjang proses pembelajaran menuju ke arah yang lebih baik.

Penerapan Model Team Quiz dengan Media Gambar dapat dijadikan sebagai alternatif dalam meningkatkan partisipasi siswa dalam belajar. Selain itu Pada pembelajaran berbicara mata pelajaran Bahasa Indonesia di kelas $\mathrm{V}$, guru hendaknya memilih media yang tepat dan dapat digunakan secara evektif. Misalnya menggunakan media gambar dalam upaya memaksimalkan keterampilan berbicara siswa. Dan juga Siswa hendaknya selalu giat untuk belajar menigkatkan keterampilan berbicara dan dalam mengikuti kegiatan pembelajaran turut berperan aktif dalam proses pembelajaran karena tanpa adanya kesungguhan dalam diri siswa, maka hasil yang dicapai akan kurang memuaskan.

\section{DAFTAR PUSTAKA}

Anitah, S. 2009. Teknologi Pembelajaran. Surakarta: Yuma Pustaka

Depdiknas. (2003). Undang-undang Sistem Pendidikan Nasional. Jakarta: Sinar Grafika

Jansen, E. (2008). Brain-Based Learning. Terj. Narulita Yusron. Yogyakarta: Pustaka Belajar.

Deporter, B., Reardon, M., Singer Nourie, S. (2011), Quantum Teaching. Bandung: Kaifa

Slameto, 2003. Belajar dan Faktor - Faktor Yang mempengaruhinya. Jakarta: PT Rineka Cipta.

Sugiyono. 2008. Metode Penelitian Pendidikan (Pendekatan Kuantitatif, Kualitatif, dan $R \& D)$. Bandung: Alfabeta

Wiriatmadja. 2008. Metode Penelitian Tindakan Kelas untuk Meningkatkan 